\title{
Handbook of Florida Fence and Property Law: Eminent Domain 1
}

Michael T. Olexa and Joshua A. Cossey²

\section{Foreword}

With approximately 19,000 livestock farms in the state, along with horse farms, orange groves, soybeans, sugarcane, cotton, peanuts, and many other agricultural and livestock facilities, livestock and farming have a significant impact on Florida's economy. Florida's agricultural economy has been required to co-exist with rapid population and commercial growth in the state over the last twenty-five years. Conflicts between these interests bring to prominence issues such as the rights and responsibilities of adjoining landowners, farmers, and property owners in general. Due to the added importance placed on these areas of real property, the legal aspects of fences in the state of Florida have taken on significant importance.

This handbook is designed to inform property owners of their rights and responsibilities in terms of their duty to fence. Discussed areas include a property owner's responsibility to fence when livestock is kept on the property, the rights of adjoining landowners to fence, the placement of fences, encroachments, boundary lines, easements, contracts, nuisances, and a landowner's responsibilities towards persons who enter his property.

This handbook should provide a basic overview of many rights and responsibilities that farmers and farmland owners have under Florida's fencing and property law. Readers may value this handbook because it informs them about these rights and responsibilities. However, the reader should be aware that because the laws, administrative rulings, and court decisions on which this booklet is based are subject to constant revision, portions of this booklet could become outdated at any time. This handbook should not be viewed as a comprehensive guide to fencing and property laws. Additionally, many details of cited laws are left out due to space limitations. This handbook should not be seen as a statement of legal opinion or advice by the authors on any of the legal issues discussed within. This handbook is not a replacement for personal legal advice, but is only a guide to inform the public on issues relating to fencing and property laws in Florida. For these reasons, the use of these materials by any person constitutes an agreement to hold the authors, the Institute of Food and Agricultural Sciences, the

1. This is EDIS document FE679, a publication of the Food and Resource Economics Department, Florida Cooperative Extension Service, Institute of Food and Agricultural Sciences, University of Florida, Gainesville, FL. This information is included in the Handbook of Florida Fence and Property Law, Circular 1242. Published November 1999; revised December 2006. Please visit the EDIS website at http://edis.ifas.ufl.edu.

2. Michael T. Olexa, Professor, Food and Resource Economics Department, and Director, UF/IFAS Agricultural Law Center, Florida Cooperative Extension Service, Institute of Food and Agricultural Sciences, University of Florida, Gainesville, FL; and Joshua A. Cossey, third-year law student, Levin College of Law, University of Florida, Gainesville, FL.

The Institute of Food and Agricultural Sciences (IFAS) is an Equal Opportunity Institution authorized to provide research, educational information and other services only to individuals and institutions that function with non-discrimination with respect to race, creed, color, religion, age, disability, sex, sexual orientation, marital status, national origin, political opinions or affiliations. U.S. Department of Agriculture, Cooperative Extension Service, University of Florida, IFAS, Florida A. \& M. University Cooperative Extension Program, and Boards of County Commissioners Cooperating. Larry Arrington, Dean 
Agricultural Law Center, and the University of Florida harmless for any liability claims, damages, or expenses that may be incurred by any person as a result of reference to or reliance on the information contained in this booklet.

\section{Acknowledgments}

The authors are indebted to Jeffrey R. Dollinger, Esq., Adjunct Professor at the University of Florida Levin College of Law and shareholder in Scruggs \& Carmichael P.A., in Gainesville, Florida, for his assistance in critiquing the manuscript draft.

\section{What is eminent domain?}

The Fifth Amendment to the United States Constitution allows the government to take private property if the taking is for a public use and the owner is "justly compensated" (usually, paid fair market value) for his loss. A public use is virtually anything that is sanctioned by a federal or state legislative body, but such uses may include roads, parks, reservoirs, schools, hospitals, or other public buildings. This procedure is sometimes called condemnation, a taking, or expropriation. For example, the proceedings to take land under eminent domain are typically referred to as "condemnation" proceedings.

\section{The process of eminent domain?}

The legal procedures surrounding eminent domain law vary significantly between jurisdictions. Usually, when a unit of government wishes to acquire privately held land, the following steps are followed:

- The government attempts to negotiate the purchase of the property for fair value.

- If the owner does not wish to sell, the government files a court action to use eminent domain, and gives notice of the hearing as required by law.

- At the hearing, the government must show that it tried in good faith to negotiate a purchase of the property, but that no agreement was reached. The government must also show that the taking of the property is for a public use, as defined by law.
- The property owner is given the opportunity to respond to the government's claims.

- If the government wins the hearing, another proceeding is held to establish the fair market value of the property. The government's payment first goes to satisfy any mortgages, liens, and encumbrances on the property, with any remaining balance paid to the owner.

\section{What is a taking?}

There are numerous types of takings which can occur through eminent domain:

- Partial Taking. If the taking is part of a piece of property, such as the condemnation of a strip of land to expand a road, the owner should be compensated both for the value of the strip of land and for any effect the condemnation of that strip has on the value of the owner's remaining property.

- Temporary Taking. Part or all of the property is appropriated for a limited period of time. The property owner retains title, is compensated for any losses associated with the taking, and regains complete possession of the property at the conclusion of the taking. For example, a temporary taking may be used to placing a large sign or setback on a neighboring property for a highway project.

- Easements and Rights-of-Way. Eminent domain actions are sometimes used to get an easement or right-of-way. For example, a utility company may obtain an easement over private land to install and maintain power lines.

- Complete Taking. In a complete taking, all of the property at issue changes use, control, and/or accessibility.

\section{How is fair value determined?}

Fair value is the highest price somebody would pay for the property (referred to as fair market value), given that a willing seller is present. The time upon which the value is assessed varies, depending upon the governing law. 


\section{Recent changes in eminent domain law (The Kelo decision)}

Several criticisms and concerns regarding the use of eminent domain by units of government point to abuses in discretion and self serving private interests.

A recent U.S. Supreme Court decision ruled that local governments have broad power to confiscate private property in the name of economic development (see Kelo v. City of New London, 125 S. Ct. 2655, 2664 [U.S. 2005]). Homeowners claimed that the city was trying to illegally force them to sell their property. The city wanted the land to make way for hotels, office buildings, and other privately funded facilities. A 5-4 ruling found in favor of the local government in New London. Due to public outcry, this decision resulted in many reactions by state legislatures to clearly define the limits and purposes of eminent domain, public purpose, and public use. Most recently, Florida passed several comprehensive changes to its own eminent domain laws.

\section{What are Florida's laws on eminent domain?}

The Legislature recently made several significant changes to Florida's eminent domain law. Newly created Fla. Stat. section 73.013 provides detailed limitations on those instances where land is pursued under eminent domain for a "natural person or private entity." Additionally, the use of eminent domain to prevent or eliminate slums, blight, or public nuisance is no longer considered a valid public purpose under section 6(a), Art. X of the State Constitution (Fla. Stat. section 73.014). In reaction to the Kelo decision, Florida voters passed a constitutional referendum (amendment 8 ) prohibiting the use of eminent domain to transfer private property to a natural person or private entity. To receive an exception to this rule requires a $3 / 5$ majority vote from both the Florida House and Senate. The specific language of Florida's eminent domain laws can be found in Fla. Stat. section 73.021 and chapters 127 and 163.

\section{Summary}

The power of eminent domain allows a unit of government (federal, state, local, or special district) to force the sale of a property for a public purpose in exchange for just compensation. This process entails a series of negotiations, followed by hearings to determine whether the exercise of eminent domain is justified. After determining whether the taking is for a public purpose, a determination is made as to the fair value of the property. Recent decisions, such as Kelo v. City of New London, clarified the Supreme Courts stance on what constitutes a defensible use of eminent domain power for economic development. However, Florida's legislature has restricted the use of eminent domain when it is used to reallocate the land to a natural person or private entity.

\section{Further Information}

Circular 1242, Handbook of Florida Fence and Property Law http://edis.ifas.ufl.edu/ TOPIC_BOOK_Florida_Fence_and_Property_ Law 